\title{
Specyfika dolnośląskich druków ulotnych z lat 1945-1948 w kontekście tradycji wydawnictw efemerycznych
}

Wydawnictwa efemeryczne od zawsze były istotnym narzędziem komunikowania, efektywnym nośnikiem treści politycznych, informacyjnych i propagandowych, a często stanowiły jedyne dostępne na danym obszarze medium. W literaturze anglojęzycznej wydawnictwa efemeryczne są określane jako ephemera, a nazwa czerpie ze źródłosłowu greckiego i pojęcia ephemeron (epi - o, na, do; hemera - dzień), odwołuje się więc do czegoś, co trwa krótko, jest aktualne przez zaledwie jeden dzień. Ephemeris - tak starożytni Grecy tytułowali swoje gazety, a na określenie grupy dokumentów, jak kalendarze czy wspomnienia, używali nazwy ephemerides (Rickards 2000, s. v). Przywołane pojęcie nie jest obce polszczyźnie, efemerydami określa się bowiem czasopisma niesystematyczne bądź krótkotrwałe, także jednodniówki (Kopaliński 1971, s. 196; STM 2006, s. 49).

Wydawnictwa efemeryczne to inaczej druki ulotne - pokaźny zbiór wchodzący w obręb niezwykle zróżnicowanego obszaru, jakim są dokumenty życia społecznego, przez bibliologów charakteryzowane jako

materiały biblioteczne o charakterze informacyjnym, normalizacyjnym, propagandowym, reklamowym, które są wynikiem działalności społecznej instytucji lub organizacji, posiadają krótkotrwałą wartość użytkową (służą doraźnej potrzebie), odzwierciedlają przejawy współczesnego życia, np. prospekty, plakaty, cenniki, ulotki, księgi adresowe, telefoniczne (PSB 2011, s. 70).

Dokumenty życia społecznego informują o przejawach aktywności danego społeczeństwa bądź określonej grupy społecznej. Choć są krótkotrwałe, efemeryczne, często odznaczają się ciekawą formą i treścią, co sprawia, że stanowią atrakcję dla bibliotek, archiwów czy kolekcjonerów (Firlej-Buzon 2002, s. 26). Obejmują szczególnego rodzaju wydawnictwa, które mogą być przedmiotem zainteresowania przedstawicieli rozmaitych dyscyplin. Ze względu na wyróżniające je cechy, takie jak mała objętość, treść dotycząca aktualnego życia publicznego, 
okazjonalność, masowe i bezpłatne rozpowszechnianie (Migoń 2006, s. 15-16), są źródłem naukowej refleksji dla bibliologów, historyków, literaturoznawców, etnologów, badaczy nauk społecznych i politycznych. Stanowią także szczególny materiał dla językoznawcy i komunikologa.

Jako nośniki wiedzy o życiu publicznym są druki ulotne przede wszystkim źródłem informacji o kształcie przekazu, formie komunikatów i tworzywie językowym, jakim w danym okresie się posługiwano. Tworzą przekaz sam w sobie - unikatowy, bo niezapisany w żadnej innej formie, tylko ulotnej i nietrwałej. Treści, które na drukach są powielane, mają trafić do konkretnej grupy odbiorców, dotyczą spraw bieżących, ponadto są przez nadawcę odpowiednio przygotowane, by skutecznie i maksymalnie wykorzystać niedużą przestrzeń, jaką oferują. Druki ulotne stanowią więc narzędzie komunikowania, delimitowane niedużym formatem medium drukowane, którego celem jest przekazanie intencjonalnie przez nadawcę przygotowanych treści, tak aby trafiły do jak najszerszego grona odbiorców.

Przedmiotem zainteresowania w niniejszym artykule są druki ulotne wydane i dystrybuowane w latach 1945-1948 we Wrocławiu i innych miastach Dolnego Śląska: Bolkowie, Strzelinie, Środzie Śląskiej, Legnicy, Jaworze, Dzierżoniowie, Dusznikach-Zdroju, Świdnicy, Obornikach Śląskich i Trzebnicy. Druki pochodzą ze zbiorów Gabinetu Śląsko-Łużyckiego Biblioteki Uniwersyteckiej we Wrocławiu. Wydobywane po wielu latach z magazynów tej instytucji, nie zostały jeszcze w całości udostępnione czytelnikom, a część z nich znajduje się w trakcie katalogowania. Zebrany korpus liczy 605 druków, wśród których są wielkoformatowe afisze, ulotki, broszury informacyjne, zaproszenia oraz druki szczególnego formatu, tzw. sztrajfy (z niem. Streifen — pas, smuga), będące nośnikami haseł propagandowych i sloganów. Zgromadzone w korpusie druki zostały skompletowane według klucza terytorialnego, czasowego i tematycznego. Dotyczą większych ośrodków miejskich Dolnego Śląska, obejmują okres od zakończenia II wojny światowej po symboliczną zmianę nazwy państwa na Polska Rzeczpospolita Ludowa, odnoszą się do wycinka terytorium określanego nazwą Ziemie Odzyskane, a ściślej, zasiedlania tego obszaru przez Polaków, tworzenia nowych władz administracyjnych, porządkowania i zagospodarowywania obcych dotąd terytoriów. Wydawane na Ziemiach Odzyskanych druki ulotne przekazują informację o tym, jak za pomocą języka kształtowano powojenną rzeczywistość, jak oswajano nowe ziemie, w jaki sposób przekazywano odbiorcom informacje o słuszności postanowień jałtańskich i poczdamskich, decydujących o przesunięciu się granic i zmianie miejsca zamieszkania wielu milionów ludzi. W tym kontekście są druki ulotne narzędziem propagandy, rozpowszechniania wśród odbiorców określonej wizji świata.

Przedmiotem dalszego opisu będą cechy stanowiące o wyjątkowości badanych druków, charakteryzujące ich cechy formalne i sposób zapisu, następnie tematyka, do której się odnoszą, a na koniec — sposób wartościowania rzeczywistości ${ }^{1}$.

${ }^{1} \mathrm{~W}$ przywoływanych cytatach $\mathrm{z}$ treści druków ulotnych zachowano oryginalną pisownię oraz wyróżnienia tekstu (np. pogrubienia). 


\section{Cechy formalne komunikatów}

Ze względu na dużą liczbę Niemców, którzy jeszcze po zakończeniu wojny zamieszkiwali Dolny Śląsk, wiele ogłoszeń, rozporządzeń, informacji przygotowywanych było w dwóch językach. Na tego typu afiszach przeważa więc dwudzielność kompozycji. Interesujące jest to, że pod względem graficznym dolnośląskie afisze powojenne są niemalże kopią afiszy niemieckich, wydawanych w czasie wojny w różnych częściach Polski. Tekst nadrzędny, w języku polskim, umieszczany jest na górze (w afiszach pionowych) bądź po lewej stronie (w afiszach poziomych) i odpowiada kolejności czytania treści. Tekst w drugim języku, po niemiecku, umieszczany jest pod tekstem prymarnym lub obok niego. W afiszach niemieckich, drukowanych do końca wojny, układ jest odwrotny. Świadczy to o powojennej zmianie nadawcy komunikatów, o symbolicznej zamianie ról, a przede wszystkim o korzystaniu z jednej sztancy drukarskiej. Ponadto często polski tekst pozbawiony jest polskich znaków diakrytycznych, co wynika z faktu, że drukarze korzystali z pozostawionych na tym obszarze maszyn niemieckich dostosowanych do obcej pisowni, niemających typowo polskich czcionek. Ów brak jest szczególnie widoczny w materiałach pochodzących z drukarń lokalnych. $\mathrm{Na}$ wydawanych przez nie afiszach widać niejednokrotnie ręczne dopiski - kropki i kreski - zwłaszcza przy bardziej eksponowanych elementach, jak nagłówek czy wezwanie do odbiorcy. Drukarski deficyt z czasem zażegnano i korzystano z urządzeń dostosowanych do specyfiki polszczyzny, niemniej zwłaszcza pochodzące z 1945 roku dolnośląskie druki ulotne charakteryzują się dwudzielnym układem treści i częstym brakiem polskich znaków diakrytycznych.

Wyodrębnione druki stanowią ponadto swoisty palimpsest, świadczący o nadpisywaniu kultur, tradycji, historii kolejnych mieszkańców Dolnego Śląska. Podczas analizy napotkano bowiem wiele afiszy korzystających z gotowych druków niemieckich. Tekst polski utrwalony został np. na odwrocie księgi przychodów (z zapisanymi w tabelach kwotami i nazwiskami obywateli niemieckich) lub na afiszach teatralnych z umieszczonym kolorowym logotypem instytucji (np. $\mathrm{z}$ winietą niegdysiejszego teatru miejskiego w Jaworze - Stadttheater Jauer). Wykorzystanie istniejących zasobów dyktował powojenny deficyt, a konieczność przekazywania informacji była silniejsza aniżeli brak środków. Przetrwanie dawnych, poniemieckich druków albo rezerw papieru wydawało się bardziej prawdopodobne w miastach mniej zniszczonych przez wojnę i niestrawionych pożarami.

Kolejną cechą kompozycyjną zebranych druków jest niemal zupełny brak grafiki. Pod tym względem afisze zupełnie różnią się od wydawanych np. w dwudziestoleciu międzywojennym lub w późniejszych latach barwnych i technicznie dopracowanych plakatów, w których przemyślana warstwa graficzna dominuje nad treścią. Jedynymi (i występującymi nielicznie) symbolami graficznymi na drukach dolnośląskich z lat 1945-1948 są logotypy, godła, znaki charakterystyczne dla pewnych instytucji bądź drobne rysunki. Cecha ta powoduje, że druki, o których 
mowa, są przesycone treścią. Cel komunikacyjny, przekazanie jak największej ilości informacji, wydaje się prymarny, ważniejszy nawet od tego, że znaczne nagromadzenie treści powoduje trudności w lekturze. Gęsto zadrukowane afisze stanowią znaczną część korpusu. Jako nośnik lapidarnych komunikatów, zwłaszcza haseł i sloganów, wykorzystywane były przestrzenie innego formatu, tzw. sztrajfy.

\section{Tematyka druków}

Każdy pojedynczy druk ulotny przypomina artefakt, który niesie informację wsobną, o właściwościach indywidualnych, i który odnosi do rzeczywistości poza sobą, do konkretnych pojęć i zjawisk. Spektrum tematyczne zebranego materiału jest bardzo szerokie, jednak analizując zebrane materiały, udało się wyodrębnić trzy spójne obszary tematyczne druków.

Gros komunikatów dotyczy spraw bieżących — lokalnych bądź ogólnopanstwowych, związanych z wprowadzanymi na danym terenie regulacjami, normami, porządkiem. Ich nadawcą są przede wszystkim urzędy miast, lokalni włodarze, inspektoraty, także pełnomocnicy rządu na poszczególne obwody administracyjne. Poruszane $\mathrm{w}$ tej grupie zagadnienia dotyczą np. obowiązkowych szczepień, akcji meldunkowej, rejestracji ludności, zakazu bezprawnego zajmowania lokali czy rozpoczęcia roku szkolnego. Charakteryzują się zwartą strukturą, dominacją funkcji informacyjnej, zwróceniem uwagi na istotność komunikatu poprzez tytuł (Wezwanie!, Uwaga!, Obywatele!). Ta grupa druków niesie informacje doraźne, związane z aktualnymi działaniami podejmowanymi przez władze administracyjne. We Wrocławiu np. takim celom służyły też głośniki i miejski radiowęzeł, który dwukrotnie w ciągu dnia nadawał ważne komunikaty, jednak nieduży zasięg tej instalacji powodował niedostateczne docieranie informacji do obywateli (Ordyłowski 1991, s. 188). Umieszczane w wielu częściach miasta afisze wydawały się równie dobrym środkiem komunikowania.

Drugą i nie mniej pokaźną grupą są wydawnictwa poświęcone kulturze i rozrywce. Już w pierwszych miesiącach po wojnie organizowano liczne zabawy taneczne (być może w myśl idei propagowanej przez jedną z gazet, że „trzeba odtańczyć wszystkie lata wojny" (Ordyłowski 1991, s. 186)), koncerty, spektakle, odczyty, seanse filmowe, turnieje piłki nożnej. Wrocławski sezon operowy zainaugurowała we wrześniu 1945 roku Halka. Na deskach teatralnych i operowych wystawiano dzieła zarówno twórców rodzimych (Aleksandra Fredry, Juliusza Słowackiego, Michała Bałuckiego), jak i zagranicznych (Ladislasa Fodora, Giuseppe Verdiego, Giacoma Pucciniego). Zapraszano na koncerty orkiestr jazzowych (Pierwszorzędna orkiestra Jazzowa - Bufet obficie zaopatrzony - Atrakcje i niespodzianki - Sala dobrze ogrzana), koncerty (Marysia Żerańska - urocza wodewilistka $w$ wesolych piosenkach) i pokazy taneczne ( $W$ programie występy solistów, oryginalny amerykański „,STEP” / Najnowsze szlagiery: polskie, rosyj- 
skie, amerykańskie, angielskie). Jak pokazują afisze, panuje względna dowolność w doborze repertuaru, a w ofertach kulturalnych wiele jest propozycji, które kilka lat później mogłyby być uznane za „przejaw zachodniego imperializmu” lub zwyczajnie zakazane.

Trzecią grupą druków są wydawnictwa inspirowane polityką, wydane przez organizacje polityczne lub też o bieżących wydarzeniach politycznych traktujące. Druki te odznaczają się dominacją funkcji perswazyjnej, a celem większości z nich jest nakłonienie odbiorcy do przyjęcia odpowiedniej postawy bądź podjęcia określonych działań (np. oddania głosu, uczestniczenia w manifestacji). Do grupy tej zaliczono afisze wydane z okazji świąt państwowych, rocznic, oficjalnych obchodów. Za przykłady takich komunikatów niech posłużą: fragment afisza wydanego w 1948 roku w Strzelinie na Święto Odrodzenia (22 lipca) oraz przytoczona w całości odezwa, pochodząca z Wrocławia z 1946 roku:

Okna, wystawy sklepowe i balkony winny być udekorowane kwiatami, dywanami i portretami Dostojników Państwa. Wyrażam nadzieję, że miasto nasze przybierze w dniu tym naprawdę odświętny wygląd (Strzelin, lipiec 1948).

\section{Odezwa}

Do właścicieli sklepów, lokali i zakładów przemysłowych

W dniu 8 maja r. b. obchodzić będzie Wrocław pierwszą rocznicę swego wyzwolenia, a dnia 9 maja r. b. odbędą się we Wrocławiu Ogólnokrajowe Uroczystości Zwycięstwa i Pokoju.

Obowiązkiem Waszym jest uprzątnięcie zakładów pracy oraz udekorowanie okien wystawowych, a szlachetną rywalizację w tym względzie oceni niewątpliwie ludność miasta i przybyli goście.

Akcja ta jest obowiązkiem każdego obywatela, od którego nikt uchylić się nie powinien.

Pełnomocnik Rządu R. P. na miasto Wrocław Inż. A. Wachniewski (Wrocław, maj 1946).

Opisywane w drukach wydarzenia wiążą się z projekcją określonych zachowań, a masowy udział w zgromadzeniach ma scalać niejednorodną, jeszcze sobie obcą grupę przybyszów na Ziemie Odzyskane. W odniesieniu do druków o tematyce politycznej można zauważyć pewną tendencję: ich liczba wzrasta wraz ze zbliżającymi się ważnymi wydarzeniami o ogólnopaństwowej skali. Pierwszym z nich jest referendum ludowe, które odbyło się 30 czerwca 1946 roku i przed którym agitowano za głosowaniem ,3 razy tak”. Drugie to odbywające się 19 stycznia 1947 roku wybory do Sejmu Ustawodawczego. Obydwu okazjom poświęcono sporo miejsca zarówno na wielkoformatowych afiszach, jak i na drobnych dru- 
kach - ulotkach, broszurach, w listach. Ich niezwykle ciekawa forma oraz cechy języka polityki mogą stać się przedmiotem osobnej, rozbudowanej analizy.

Tematycznym spoiwem łączącym wszystkie druki jest jednak obszar, na którym zostały wydrukowane i do którego się odnoszą. To powojenna rzeczywistość Ziem Odzyskanych jest asumptem do ich wydawania - wymusza konieczność wprowadzania określonych regulacji, odcina się od wojennej traumy i prowokuje do powrotu realiów przedwojennych, obfitujących w wydarzenia kulturalne i rozrywkowe, a ponadto obrazuje ścieranie się politycznych sił w tym regionie, w latach 1945-1948 jeszcze pluralistycznych i prezentujących różne punkty widzenia.

\section{Językowy kształt druków dolnośląskich}

Językowym tworzywem druków dolnośląskich jest polszczyzna ogólna, oficjalna, w której nie pojawiają się regionalizmy ani elementy gwarowe. Ujednolicenie stylistyczne wynika $\mathrm{z}$ faktu, że odbiorcami komunikatów byli ludzie pochodzący z różnych części kraju, często także z zagranicy (wcześniej przebywający np. na robotach przymusowych), o różnym doświadczeniu edukacyjnym i odmiennych kompetencjach komunikacyjnych. Druki ulotne - jako przekazy kierowane do ogółu - czerpią więc z języka uniwersalnego. Wyjątek stanowią jedynie afisze adresowane do ludności żydowskiej, szczególnie w Dzierżoniowie, Świdnicy i Wrocławiu. Materiały te są niejednokrotnie opatrzone tekstem hebrajskim i zawierają elementy leksykalne charakterystyczne dla tradycji żydowskiej (np. zaproszenie na bale purimowe i wieczory chanukowe czy nazwy organizacji: Keren Kajemet LeIsrael, Poale-Sjon).

Zróżnicowanie profilu mieszkańców Dolnego Śląska, a przede wszystkim liczna obecność cudzoziemców, wymuszały konieczność lub chęć formułowania treści dwujęzycznych. Jak zasygnalizowano wcześniej, liczebnie wyróżniają się na tym tle afisze polsko-niemieckie, niosące informacje np. o wysiedleniu bądź rejestracji ludności autochtonicznej, o opłatach podatkowych czy zakazie wywozu ruchomości. Drugą, mniej liczną grupą zagranicznych odbiorców byli Rosjanie, przede wszystkim żołnierze podlegający tutejszym komendanturom. Teksty polsko-rosyjskie dotyczyły zwłaszcza wydarzeń rozrywkowych, koncertów, inscenizacji czy pokazów filmowych. W całym zbiorze natrafiono również na afisz polsko-włoski, zatytułowany Wezwanie do Włochów, opatrzony obrazkiem flagi, na której zapisano ITALIANI!. Jedyny taki afisz, wzywający do rejestracji tych obywateli Włoch, którzy chcieliby wrócić do ojczyzny, jest świadectwem działalności we Wrocławiu Komitetu Włoskiego i obecności na Dolnym Śląsku Włochów — najprawdopodobniej jeńców wojennych (Firlej-Buzon 2013, s. 138-139).

Kształt językowy druków różnicuje nie tylko odbiorca, lecz także tematyka przekazów. Komunikaty stricte informacyjne obfitują w detale administracyjne, powołują się na numery ustaw, często tworzą treść opartą na wyliczeniach, a pod 
względem składniowym wyróżniają się konstrukcjami bezosobowymi (Ogłasza się przeto zapisy do szkót powszechnych oraz średnich ogólnoksztatcacych $i$ zawodowych; Podaje się do wiadomości, iż zajęcia w szkołach na terenie Wroctawia rozpoczną się dnia 4 września 1945 r.). Afisze rozrywkowe i kulturalne są krótkie, a podawane szczegóły mają charakter hasłowy. Przeważa funkcja informacyjna, mówiąca o wykonawcach lub temacie, miejscu i czasie wydarzenia. Najbardziej heterogeniczną grupę stanowią druki o tematyce politycznej. Zróżnicowane pod względem stylistycznym, zawierają przekaz silnie oceniający, przede wszystkim za pomocą leksykalnych środków prymarnie wartościujących.

Przykładem pojęcia najczęściej wartościowanego, do którego odnosi się duża część tekstów, jest sam termin „Ziemie Odzyskane”. Nawiązując do niego, nadawcy druków stworzyli bogatą sieć synonimów, złożonych najczęściej z metonimii i peryfraz, wnoszących do opisu sztafaż sugerowanych cech, z którymi opisywane terytoria powinny się kojarzyć. Najczęściej w charakteryzowaniu Dolnego Śląska odwoływano się do dawnych czasów pierwszych Piastów, stąd określenia: prastara ziemia Chrobrego, starodawne ziemie piastowskie, prastare ziemie piastowskie, odwieczne piastowskie ziemie, prastare Ziemie Piastowskie — najczęściej trzyskładnikowe, których najważniejszym komponentem są „ziemie”. Zdarzają się także określenia krótsze, wskazujące na przynależność (np. ziemia Bolesławów), bądź dopełnione dłuższym opisem, wskazujące na szczegół historyczny lub topograficzny (nasze prastare Ziemie Piastowskie, które po 600-letniej niewoli powrócity juz na zawsze do Macierzy; prastare ziemie piastowskie, przez lat 600 oderwane od Macierzy; prastare ziemie Piastowskie nad Odra i Nissa). Dla oswojenia nowych terytoriów i sugerowania odbiorcy, że jest częścią wspólnoty winnej się o to „odwieczne” dziedzictwo troszczyć, używa się zaimka inkluzywnego, obejmującego niesprecyzowaną, a przez to pojemną grupę (Nasze Ziemie; Ziemie Zachodnie sa i pozostana nasze). Wspólnotowość podkreślana jest także przy użyciu bardziej rozbudowanych formul:

Powróciliśmy na te odwiecznie polskie ziemie, nierozerwalnie związane z Bałtykiem szarą wstęgą Odry, aby je raz na zawsze z Ojczyzną zjednoczyć (Legnica 1945).

Dzisiaj, gdy po prawie 600 latach powróciliśmy na prastare ziemie piastowskie, na dawny szlak dróg wodnych łączących Śląsk z Bałtykiem, odzyskaliśmy szeroki dostęp do morza, staliśmy się państwem morskim, musimy to odpowiednio wykorzystać (Dolny Śląsk 1946).

Zaprezentowane przykłady są częścią wszystkich wynotowanych określeń, częścią sugerującą motywy, jakie pojawiały się w określaniu przyłączonych do Polski terytoriów - obszaru, na którym analizowane druki były wydawane i dystrybuowane. 
W toku analizy treści druków dostrzeżono ponadto dychotomię w sposobie wartościowania świata. Już sam termin „Ziemie Odzyskane” sugeruje wcześniejszą utratę terenów, do których się odnosi, a nadawcy druków sugerują niezmiennie, że winnymi utraty są Niemcy. Do Niemców odnosi się najwięcej wyrażeń i tropów wartościujących negatywnie, obraźliwych, o wyraźnych cechach agresji językowej (Kamińska-Szmaj 2007, s. 52). Formuły obelżywe mają najczęściej dwu- lub trzyelementową konstrukcję, z których jeden składnik jest silnie wartościującym epitetem, wskazującym na trwanie lub określoną ideologię: odwieczny wróg; faszystowski najeźdźca; zbrodniczy hitleryzm; okupant hitlerowski; barbarzyński najeźdźca. W określeniach sięga się także do negatywnie wartościowanej sfery świata zwierzęcego (gad hitlerowski; bestialski hitleryzm). Negatywnie konotowany jest przymiotnik niemiecki - leksykalnie neutralny, umieszczony zostaje w kontekstach wyłącznie negatywnych (niemiecki okupant; niemiecki imperializm; niemieccy mordercy).

Także negatywnie, choć nie tak często jak Niemcy, charakteryzowani są przedstawiciele „świata Zachodu” - jako imperialiści anglosascy, międzynarodowy imperializm, zagraniczna reakcja. Jako wróg postrzegani są ci, którzy nie aprobują powojennego przesunięcia granic, choć zwykle pozostają oni nienazwani, przedstawiani jako grupa, ogół, np. na afiszu Wojewódzkiego Komitetu Żydowskiego, który wzywa do udziału w wiecu protestacyjnym (Wrocław, wrzesień 1946), mowa jest o akcji przeciwko zakusom anglosaskich kół reakcyjnych, wymierzonym w całość zachodnich granic Rzeczypospolitej.

Znamienne, że w pierwszych latach po wojnie w treści afiszy negatywnie wartościowani są tylko przedstawiciele zagranicy. Wrogowie „wewnętrzni” napiętnowani zostają przy okazji pierwszych poważnych sporów o władzę i dominację w państwie. Rozbijanie klasy chłopskiej przypisuje się w oficjalnych drukach Polskiemu Stronnictwu Ludowemu, początkowo piętnowanemu w aluzjach, a przed wyborami do Sejmu Ustawodawczego - już bezpośrednio:

Reakcja zagraniczna i jej poplecznicy w Kraju grupujący się w szeregach P. S.

L. krzyczała na cały świat, że nam ziemie nad Odrą i Nysą nie są potrzebne.

[...] Dzień 19 stycznia 1947 r. to dzień wielkiej manifestacji ludu pracującego,

to dzień odpowiedzi na wszelkie zakusy reakcji zagranicznej i P. S. L. zmie-

rzające do odebrania nam Ziem Odzyskanych i powrotu do rządów z przed

1939 roku, które taką klęskę przyniosły Narodowi (Trzebnica 1947).

Otwarte ataki słowne na przeciwników politycznych oraz widoczna w powyższym przykładzie negacja przeszłości, zwłaszcza okresu sprzed 1939 roku, stanowią już próbkę tego, co jest charakterystyczne dla języka propagandy politycznej późniejszego PRL-u. Ewolucja kształtu przekazów utrwalonych na afiszach, proces pojawiania się i krzepnięcia stałych form językowych, pozwala na potraktowanie przyjętego okresu, lat 1945-1948, jako stanu przejściowego, interesującego dla badacza pomostu łączącego dwa różne typy komunikowania. 
Oprócz negatywnego wartościowania $\mathrm{w}$ analizowanych drukach częste są przykłady nobilitacji. Odnoszą się one przede wszystkim do Rosjan, nazywanych sojusznikiem oraz bratnim słowiańskim narodem. Pozytywne wartościowanie odbywa się poprzez dobór słownictwa prymarnie wartościującego, formy przymiotnikowe i rzeczownikowe, które jednoznacznie wskazują na pozytywny aspekt działania. Uwypuklaną w opisach cechą jest zwłaszcza pomoc Polakom w zwycięskim zakończeniu wojny, wspomina się także o podobieństwie mentalnym i historycznym obu narodów. Nobilituje się Rosjan w ogóle, ale szczególnie podziwiani są żołnierze Armii Czerwonej. Poświęcono im wiele afiszy, na których opiewa się ich zwycięskie czyny, dodając niekiedy, że towarzyszyli im również żołnierze polscy. Znamienne, iż Polacy są przedstawiani „obok”, u boku:

Bohaterskie Wojsko Polskie u boku Armii Czerwonej przeszło chlubną drogę bojową, zatknęło sztandar zwycięski nad Berlinem i stanęło mocną nogą na Odrze, Nysie i Bałtyku (Wrocław, lipiec 1946).

Podziw u nadawców afiszy budzi potęga sąsiada, zarówno liczebna, jak i militarna. Polska przedstawiana jest jako kraj, który z obrazu Rosji może czerpać szlachetne wzorce i dążyć do podobnego ideału, co widać w przykładach pochodzących zarówno z początku badanego okresu (1945 rok), jak i z końca (1948 rok):

Wraca nasz naród pod wodzą tych patriotów, którzy zrozumieli, że jedynie sojusz z bratniemi słowiańskiemi narodami a przedewszystkiem, krwią polskiego i radzieckiego żołnierza przypieczętowany, sojusz polsko-radziecki daje nam możliwości naprawdę mocarstwowego rozwoju (Legnica 1945).

W dniu 1 Maja obchodzimy święto wszystkich ludzi pracy, Święto klasy robotniczej, pracującej inteligencji i postępowego mieszczaństwa pod znakiem: Zjednoczenia całej młodzieży demokratycznej, Jedności Polskiego ruchu robotniczego, jako efektywnego wyrazu postępującej konsolidacji sił, postępu pokoju i demokracji. Konsolidacji Narodów Słowiańskich i sił postępowych świata wokół Związku Radzieckiego, jako ostoi pokoju i przeciwwagi dla kapitalistycznych imperialistów anglosaskich i ich satelitów (Strzelin 1948).

Interesujące jest to, że przekazy na temat Rosjan nie zmieniają swojego nasilenia w badanym okresie. O ile np. negatywnie wartościujących tekstów w odniesieniu do Niemców i zagranicznej reakcji więcej było w pierwszych miesiącach po zakończeniu wojny, o tyle w przypadku treści nobilitujących Rosjan tendencja do chwalenia i uwypuklania pozytywnych cech się utrzymuje. Sprzyjają temu organizowane święta, które przywołują zasługi Armii Czerwonej, takie jak kolejne rocznice wyzwolenia poszczególnych miast, lub też podejmowane przez lokalne władze inicjatywy, np. organizowanie na Dolnym Śląsku kół Towarzystwa Przyjaźni Polsko-Radzieckiej.

Znane z późniejszych przekazów historycznych negatywne aspekty działalności Armii Czerwonej na Ziemiach Odzyskanych, takie jak kradzież bądź nisz- 
czenie mienia, są przemilczane na wielkoformatowych drukach, podobnie jak temat rzeczywistej rekompensaty za terytoria utracone na Wschodzie. Zagadnienia te poruszył Hilary Minc, ówczesny minister przemysłu, podczas I Zjazdu Przemysłowego Ziem Odzyskanych, który odbył się w sierpniu 1945 roku. Jego przemówienie zostało wydrukowane w „Głosie Robotniczym”, a następnie powielone jako osobna ośmiostronicowa broszura zatytułowana Nowa karta dziejów Polski. Druk ten jako jedyny spośród wszystkich zawiera wzmiankę na temat utraconych ziem. Polityk przedstawia je jako mniej wartościowe, a do tego historycznie przynależne Ukraińcom i Białorusinom:

W rezultacie tej wojny zmieniła się gruntownie nasza pozycja w Europie. Zmieniło się miejsce przez nas zajmowane. Przesunęło się państwo nasze na zachód. Utraciliśmy tereny w większości ukraińskie i białoruskie na wschodzie, rozszerzyliśmy się potężnie na zachodzie i w jednym wielkim skoku dziejowym osiągnęliśmy Bałtyk, Odrę, Nissę (oklaski). [...] Jeżeli teraz zestawimy ten nowy potężny przemysł na Ziemiach Zachodnich z tym co utraciliśmy na wschód od Bugu, to wniosek, niezbity wniosek, któremu nikt nie może zaprzeczyć, będzie brzmiał: $\mathrm{w}$ dziedzinie przemysłu przetwórczego rachunek strat i zysków układa się na naszą korzyść (s. 1).

Dziejowy skok wypada, zdaniem Minca, na plus. Z kolei opinie na temat dezynwoltury Rosjan na Ziemiach Odzyskanych, grabieży i wywózek przez nich dokonywanych, nazywa wroga propaganda, natomiast udostępnienie im sprzętów i urządzeń - umową dżentelmeńska i przyjacielską:

[...] słyszy się często, — działa w tym kierunku wroga propaganda - że $\mathrm{z}$ tych bogactw, $\mathrm{z}$ tego potencjału gospodarczego w rezultacie działalności Armii Czerwonej, w rezultacie tzw. wywózek i demontażu nie zostało nic. Przyszedł czas, żeby o tej sprawie powiedzieć prawdę jasno, wyraźnie. Między Rządem Polskim a Rządem Związku Radzieckiego zawarty został układ, który pozwala, który pozwalał raczej na skorzystanie ze strony Związku Radzieckiego z części urządzeń przemysłowych na terytoriach niemieckich, które nam przypadają. Uważaliśmy, mając przed oczyma obraz kolosalnych zniszczeń dokonanych przez Niemców w Rosji, zniszczeń, wobec których nasze zniszczenia bledną i maleją i mając przed oczyma obraz niezmiernych cmentarzy rosyjskich, na których leżą żołnierze padli w walce o te ziemie, uważaliśmy, że mamy moralne prawo zawrzeć taki układ i sądzimy, że jeżeli w rezultacie tego układu podział na terenach poniemieckich został dokonany $w$ ten sposób, że $25 \%$ urządzeń przemysłowych, a $6 \%$ ogólnego majątku przypadło Związkowi Radzieckiemu, to wobec ogromu zniszczeń rosyjskich i ogromu strat poniesionych przez Rosję układ ten nie może być nazwany inaczej jak dżentelmeńskim i przyjacielskim (oklaski) (s. 4). 
W zręcznym retorycznie wystąpieniu, przerywanym wielokrotnie oklaskami, o czym informuje zapis tekstowy, polityk zdaje się nie stronić od trudnych i nieobecnych w szerszym dyskursie tematów. Podejmuje je jednak w łatwy do przewidzenia sposób. Broszura z przemówieniem Hilarego Minca jest ciekawym przykładem druku, który zarówno formalnie, jak i treściowo wyróżnia się na tle pozostałych wydawnictw.

Analizowane druki, kierowane do masowego odbiorcy, zakotwiczone w konkretnej rzeczywistości i podejmujące bieżące zagadnienia, nie odbiegają od tradycji wydawnictw efemerycznych. Ich cechy formalne pozwalają na umieszczenie ich w pojemnej grupie materiałów, które od wieków towarzyszyły społecznej działalności człowieka i podejmowanym przez niego próbom rozpowszechniania i zdobywania najważniejszych informacji.

Zebrany do badań korpus 605 dolnośląskich druków ulotnych tworzy unikatowy pod wieloma względami zbiór form. Może stanowić punkt wyjścia do badań interdyscyplinarnych, ale różnorodność tematyczna, kompozycyjna i stylistyczna jest wartościowym asumptem do rozważań natury językoznawczej. W artykule wymuszającym skrótowość została przedstawiona część spośród dużej liczby zagadnień, jakie można poruszyć w toku dogłębnej analizy. Proponowane aspekty już jednak pozwalają stwierdzić, że specyfika dolnośląskich druków ulotnych wynika przede wszystkim z obszaru, na którym zostały wydane i były powielane, a także — którego to obszaru dotyczą. Problematyka Ziem Odzyskanych, zagospodarowania ich i oswojenia jednocześnie wymusza przyjęcie określonych form komunikowania oraz staje się przedmiotem opisu. Sposób kreowania spójnej wizji świata jest podyktowany pragmatyką, rzeczywistością społeczną i polityczną. Ponadto dyskurs dolnośląskich druków ulotnych został ukształtowany przez tendencje ogólne, wyrabiane przez politykę językową wczesnych lat powojennych. Ujawnia obecne w ówczesnym komunikowaniu strategie, takie jak uwypuklanie bądź przemilczanie określonych pojęć, ich celowe wartościowanie, a także dychotomiczny sposób przedstawiania świata.

\section{Bibliografia}

Firlej-Buzon A. (2002), Dokumenty życia społecznego w teorii i praktyce bibliotekarskiej w Polsce, Warszawa.

Firlej-Buzon A. (2013), Druki ulotne i okolicznościowe jako źródła do badań dziejów i kultury Dolnego Ślaska lat 1945-1956, Wrocław.

Kamińska-Szmaj I. (2007), Agresja językowa w życiu publicznym. Leksykon inwektyw politycznych 1918-2000, Wrocław.

Kopaliński W. (1971), Stownik wyrazów obcych i zwrotów obcojęzycznych, Warszawa.

Migoń K. (2006), Bibliologia o drukach ulotnych i okolicznościowych, [w:] Druki ulotne i okolicznościowe - wartości i funkcje, red. K. Migoń, M. Skalska-Zlat, A. Żbikowska-Migoń, Wrocław. 
Ordyłowski M. (1991), Życie codzienne we Wrocławiu 1945-1948, Wrocław.

PSB (2011), Podręczny stownik bibliotekarza, oprac. G. Czapnik, Z. Gruszka, Warszawa.

Rickards M. (2000), The Encyclopedia of Ephemera. A Guide to the Fragmentary Documents of Everyday Life for the Collector, Curator, and Historian, London.

STM (2006), Stownik terminologii medialnej, red. W. Pisarek, Kraków.

\section{Peculiarity of Polish Lower Silesian posters from 1945-1948 in the context of printed ephemera tradition}

\section{Summary}

The aim of this article is to present specificity of Polish posters, public notices, proclamations, leaflets and brochures that were printed in Lower Silesia in the years 1945-1948. All these materials refer to a long tradition of printed ephemera and seem to be unique for scientists representing many fields. However, in this article peculiarity of these materials for linguists interested in political propaganda, newspeak, language of values is shown. There were three issues presented (composition, subject matter and stylistics) which are an introduction to very detailed research on language of Polish printed ephemera.

Keywords: ephemera, regained territories, language of values, propaganda 